\title{
THE MEANING OF THE RING AND ROD IN BABYLONIAN- ASSYRIAN SCULPTURE
}

\author{
REV. ARTHUR E. WHATHAM \\ Georgetown, Del.
}

In a letter recently received from Professor C. H. W. Johns, of Cambridge, he writes: "the rod and ring, if separate, in Assyrian and Babylonian are to me quite obscure." Budge thinks these conjoined symbols are indicative of the deity's eternal existence; Pinches thinks that the circle is emblematic of his supposed journey around the earth; Ward sees in the staff the divining-rod; Jastrow sees in the combined symbols the emblematic power to mark off a boundary, the circle indicating the power to inclose, and the rod the measuring-stick, so that the deity holding these symbols may be viewed as the fixer of boundaries.

Not one of the above suggestions gives the real meaning of the symbols in question. Indeed, Jastrow asserts that "this ring and stick are certainly not symbols of royalty." This, however, is exactly what they are. In Mr. King's Seven Tablets of Creation, there is the description of the gods giving to Marduk a scepter, a throne, and a ring, upon his preparing to meet the dragon Tiamat in combat. At the time I read this passage it seemed to me that here we have a clear indication that the circle and staff given to Marduk were part of the gift indicated by the throne, viz., sovereign power. Line 28 , as given by Mr. King in his rendering of the fourth tablet, runs: "They rejoiced and they did homage (unto him, saying), 'Marduk is king.", The next line, 29, runs: "They bestowed upon him the scepter, and the throne, and the ring." Mr. King adds in a note that "the translation of patu as 'ring' is provisional; the patu was certainly a symbol of power." We have, however, to bear in mind that in Marduk undertaking the combat on behalf of the gods he is made their face; in plain language, he absorbs their personality so that he becomes even as Shamash, that is to say, the sun-god. Thus as the sun-god he takes over the emblems of the sun-god's sovereignty, the scepter, the throne, and the ring.

The above conclusion as to the significance of the circle and rod, is borne out by Dr. A. V. Williams Jackson in the American Oriental Society Proceedings for May, I889. Here he quotes from the Avesta that a golden 
ring and a golden staff had been given to Yima, who is to bear royal sway, showing that in old Iranian times the ring and staff were symbols of royalty.

That the rod here is neither a measuring-stick nor a divining-rod is amply proved by the bas-relief sculptured by order of Sennacherib, showing four figures, two standing upon animals resembling dogs, and two standing upon the ground. Two stand right and left facing each other in couples, so that we may see here in the four figures merely a repetition of a king and a deity. Now, the god carries in his hand a circle and rod, the latter adorned on the top with a palmette, showing distinctly that the rod here is intended to indicate a scepter; and, if so, in all other similar representations of a deity with a rod and circle the rod represents a scepter, the indication of sovereignty.

Can it be as clearly shown what phase of power the circle indicates as it has been shown what the rod indicates? I think so, and even with greater interest.

From the Assyrian word kuduru signifying a "boundary," Dr. Jastrow sees in the circle in the hand of the god Shamash a representation of a kuduru. In other words, he sees in this symbol, as held in the hand of Shamash, the emblem of boundary-maker. It is strange that, while he refers to Shamash's frequent title of "judge of the world," it never occurred to him to connect this world-rule with the circle in the hand of Shamash. Of course, I myself may be mistaken, but I see in this rod the symbol of supreme sovereign power over what to me the circle indicates, viz., the world. I view the circle as symbolizing the actual world, or, at all events, all the world's territory.

Now comes a most interesting connection between the modern orb of royalty and the ancient circle of sovereignty. From the age of Aristotle (born 384 B. C.) the earth ceased to be figured in the minds of astronomers and geographers as it had been previously viewed, viz., as a flat disk; henceforth it was conceived of as a sphere or globe. Bratosthenes (born $276 \mathrm{~B}$. C.) attempted to measure the size of the earth on the basis of its spherical form. Crates of Mallus about $15 \circ$ B. C. made the first globe as representing the earth's figure, dividing it into the four segments which continue to this day on the globe which forms part of the insignia of royalty, known as the royal orb. As a symbol of sovereignty the globe is of ancient Roman origin. A medallion shows the half-length figure of the emperor Galba, holding in one hand the eagle-tipped scepter, and in the other the orb surmounted by a small figure of Victory. The emperor Justinian used the orb having the cross in the place of the former symbol, to represent the ascendency of Christianity over the world. The orb as indicating world- 
sovereignty must have been well recognized before the time of the emperor Galba, since it appears with this significance in a Pompeiian wall-painting of Jupiter and in sculptures, Pompeii being destroyed in 79 A. D. Galba was murdered in $69 \mathrm{~A}$. D., but a symbol of world-sovereignty, to have been so widely recognized as to figure in Pompeiian paintings and sculpture, must have been viewed as such long before the destruction of that city. It seems to me that fully a hundred years before Christ the globe or orb as a symbol of world-sovereignty was well understood as a feature of royal insignia.

On the rock of Bagistan or Behistan, in Persia, is a carved scene representing Darius (king $52 \mathrm{I}-485$ B. C.) receiving the submission of the chiefs of the nations which had revolted against him, and whom he had subdued. Above the king there is a representation of the deity Ormazd who holds in his hand a circle. Similar representations are of frequent occurrence about this period.

The significance of this circle-in-hand, which I claim to have been always that of world-power, is well brought out in the above scene, which represents the rule of Darius over the nations of the earth. The circular form of the earth was of ancient belief among the Semites. With the Babylonians it was a hollow hemisphere, with its convex side upward. With the Hebrews it was more of a flat disk. Both peoples, however, thought of it as resting with a circular outline upon an abyss of waters.

In Prov. 8:27 we read of Yahweh having set the earth as a circle upon the face of the deep; in Ps. 24: I, 2, that the earth is his, for he made it; in Isa. 40:22, that he sitteth above the circle of the earth. In like manner, Marduk was viewed by the Babylonians as creator, and so lord, of the earth, which he formed as a hemisphere, placing it with its convex side up upon the lower watery abyss. Thus with both peoples the circle came to symbolize the world, or lordship over the world. In later ages, when the circular form of the earth gave way to its conception as a sphere or globe, an orb took the place of the circle in the hand of a deity or earthly ruler. The exact period when the change came about, and so by whom and with whom the change was first made, I am unable to say for lack of data. That the globe, however, subsequently took the place of the circle, with the same significance of world-sovereignty, I think I have clearly shown. Thus the ancient symbols of the circle and rod have been shown to be emblems of sovereignty. That the circle is not as often seen in the hand of earthly rulers as it is in that of gods and goddesses, does not alter this conclusion. There are instances where it is seen as held by the former, one having been pointed out by Madame Z. A. Ragozin, in Media, in the 
"Story of the Nations" series, p. 377 , and I am investigating others. That it is found in the hands of goddesses does but strengthen our conclusion, since these female deities were representatives of world-power equally with the male deities who carried the ring and rod.

That the circle is represented as held, instead of being supported by the hand, does not in the least affect the argument, since, the sun's disk, as usually represented, is similarly depicted as a hollow circle. 